Makay Mátyás

\title{
A MUNKAERŐ-KIVÁLASZTÁSBAN HASZNÁLT SZEMÉLYISÉGTESZTEK EGYES ELMÉLETI PROBLÉMÁIRÓL
}

Theoretical Problems of Personality Tests Used as Selection Tools

Makay Mátyás, doktorjelölt, Eötvös Loránd Tudományegyetem, Pszichológia Doktori Iskola,makay.matyas@gmail.com

A tanulmány a munkaerőpiaci kiválasztásban széles körben használt, ám tudományos szempontból gyakran a kívánatosnál kevésbé megalapozott személyiségtesztek egyes ismeretelméleti problémáival foglalkozik. Az episztemológiai megalapozottság hiányosságai a gyakorlati felhasználók körében általában kevésbé ismertek, a cikk alapvetö célja e problémák felvetése és világos artikulálása.

KulcsszavaK:

episztemológia, ismeretelmélet, személyiség, személyiségvonások, személyiségteszt

The paper provides a concise analysis of the epistemological problems of trait psychology and, especially, those of personality tests widely used as selection tools. These fundamental issues are largely unknown to experts using these tests. The main objective of the article is to provide a clear articulation of these problems.

KEYWORDS:

epistemology, personality, personality tests, personality traits 


\section{BEVEZETŐ}

A munkaerő-kiválasztási folyamat során a pszichológiai tesztek használatának komoly, több mint száz évre visszanyúló hagyománya van. A tesztek fö funkciója, hogy a kiválasztási folyamat hatékonyságát megnövelje. Az új munkaerő felvétele, betanítása költséges és időráfordítást igénylő feladat, így célszerü a kiválasztási folyamat alatt minél megbízhatóbb képet nyerni a jelentkezőnek a megcélzott munkakörre való alkalmasságáról.

A kiválasztási folyamatban leggyakrabban képesség- és személyiségteszteket használnak. A képességtesztek vagy egy-egy területre koncentrálnak, mint például a numerikus, verbális képesség, vagy ezeknek a képességeknek nagyobb csoportjára, mint a különböző komplex IQ-tesztek. Ezek a tesztek a potenciális munkatársak általános kognitív képességeit mérik fel, és így jó fogódzót kínálnak a kiválasztásban részt vevők számára annak megítéléséhez, hogy a jelentkező képes lesz-e a pályázott munkakör betöltésére. A képességtesztek általános jellemzője a viszonylag magas pszichometriai megbízhatóság és érvényesség.

A kiválasztásban használt másik teszttípus a személyiségtesztek csoportja. Ezek a tesztek nem konkrét képességeket mérnek, hanem a jelentkező személyiségvonásait és a kiválasztásban részt vevők ezekből a személyiségvonásokból próbálnak meg következtetni arra, hogy a jelölt alkalmas lesz-e a pályázott cég, illetve a betölteni kínált munkakör által kínált környezetben történő munkavégzésre.

A személyiségtesztekkel és különösen ezeknek a munkaerö-kiválasztásban történő alkalmazásával kapcsolatban sok kérdés merül fel. Ebben az írásban döntően a személyiségtesztekhez kapcsolódó elméleti, ezen belül is elsősorban ismeretelméleti problémákkal foglalkozunk. Nem célja a tanulmánynak a személyiségtesztek részletekbe menő pszichometriai elemzése, és nem foglalkozunk a személyiségteszteknek a klinikai pszichológiában - ahonnan egyébként eredetileg származnak - való felhasználásával sem.

\section{SZEMÉLYISÉGTESZTEK}

A személyiségtesztek első nagy csoportja a projektív tesztek, például a Rorschach-teszt, illetve a Rorschach típusú tesztek, a Tematikus Appercepciós Teszt (TAT) és annak változatai, vagy a Szondi-teszt. A másik csoport a strukturált vagy objektív tesztek, ezek közül igen népszerüek a Myers-Briggs teszt (MBTI - Myers Briggs Type Indicator), az MMPI-ból (Minnesota Multiphasic Personality Inventory) az 1950-es években fejlesztett CPI (California Psychological Inventory), vagy az utóbbi időben egyre elterjedtebb ötfaktoros modell (Big 5) tesztjei.

A személyiségtesztek hatalmas népszerűségnek örvendenek a munkaerő-kiválasztási területen. A Myers-Briggs tesztet évente 2,5 millió ember tölti ki és a Fortune 100 listáján 
szereplő vállalatok csaknem 90\%-a használja, ${ }^{1}$ a személyiségtesztek piaca pedig évi 2 és 4 milliárd dollár közé becsülhető. ${ }^{2}$

A munkáltatók elsősorban azért kedvelik a személyiségteszteket, mert - jórészt függetlenül tudományos alátámasztottságától, illetve igazolható eredményeitől - viszonylag könnyen és gyorsan lehet nagy mennyiségű jelentkezőből egy jóval kezelhetőbb kisebb csoportot kiszűrni. A személyiségteszt megadja azt az illúziót a munkáltatónak, hogy egy jelentkezőről egy rövid teszt segítségével mély és alapos ismereteket lehet szerezni.

A személyiségtesztekbe vetett hit erőssége megmutatkozik abban is, hogy ma a tudományos világban széleskörűen elfogadott nézet szerint például a Myers-Briggs rendszer tudományos értelemben vett alátámasztottsága rendkívül csekély. ${ }^{3}$ Közismert az önbevallásra épülő teszteknek a manipulálhatóságukból fakadó inherens megbízhatatlansága, pedig ez a faktor kiválasztási területen alapvető fontosságúnak tünik, ${ }^{4}$ ennek ellenére az ilyen típusú tesztek töretlen népszerüségnek örvendenek.

Az, hogy melyik szakértő melyik típusú személyiségtesztre esküszik, az - a jelenlegi megítélés szerint valamivel jobb pszichometriai jellemzőkkel rendelkező Big 5 teszteket leszámítva - jórészt hitbéli kérdés. Az, hogy ez önmagában milyen súlyú probléma, azt jól jelzi, hogy a magyar államigazgatásban még a 2000-es évek közepén is használták a pszichológia tudománytörténetében tisztességes helyet betöltő, de a mai tudományos kritériumoknak semmilyen értelemben meg nem felelő, az 1930-as évekből származó Szondi-tesztet, ${ }^{5}$ sőt, a gyakorlatilag az áltudomány kategóriájába tartozó grafológiai tesztet is. ${ }^{6}$

E tanulmány keretei nem alkalmasak arra, hogy a személyiségtesztek pszichometriai jellemzőit részletesen vizsgáljuk, erre egyébként számos és egymással sok tekintetben ellentmondó kutatás létezik. Egy viszonylag friss átfogó tanulmány szerint ${ }^{7}$ a személyiség és a munkaköri sikeresség között a korreláció gyakorlatilag elhanyagolható $(0,03-$ 0,15 érték). Ez a korrelációs szint nagyjából azt jelenti, hogy a kiválasztásban használt személyiségtesztek hozzávetőlegesen 5\%-ban határozzák meg a munkahelyi sikert, míg a maradék 95\% a személyiségtől független változók eredője. Külön figyelemre méltó, hogy a 0,15 korrelációs szint gyakorlatilag megegyezik az 1960-as években mért szinttel, amiből egyenesen következik, hogy a kétségtelenül sok erőfeszítés ellenére a személyiségtesztek kiválasztásban történt felhasználásának területén említésre méltó előrelépés nem történt.

Adam Grant: Goodbye to MBTI, the Fad That Won't Die. Psychology Today, 2013.

Emotional Breakdown. The Economist, 2013.

William L. Gardner - Mark J. Martinko: Using the Myers-Briggs Type Indicator to Study Managers: A Literature Review and Research Agenda. Journal of Management, 22. (1996), 1. 45-83.

4 Frederick P. Morgeson et alii: Are We Getting Fooled Again? Coming to Terms with Limitations in the Use of Personality Tests for Personnel Selection. Personnel Psychology, 60. (2007), 4. 1029-1049.

5 Scott O. Lilienfeld - James M. Wood - Howard N. Garb: The Scientific Status of Projective Techniques. Psychological Science in the Public Interest, 1. (2000), 2. 27-66.

6 Russel W. Driver - M. Donald Bruckley - Dwight D. Frink: Should We Write Off Graphology? International Journal of Selection and Assessment, 4. (1996), 2. 78-86.

Morgeson et alii (2007) i. m. 
A tanulmányban azokat az elméleti kihívásokat vesszük sorra, amelyek a jelenleg használt személyiségteszteknek sajátjai, és amelyek nehezítik ezek tudományos alátámasztottságának erősödését.

\section{AZ ELMÉLETI HÁTTÉR HIÁNYA}

Ami a személyiség, a személyiségvonások pszichológiájával kapcsolatban elsőként feltűnik, az a teoretikus-filozófiai háttér csaknem teljes hiánya. Az elméleti háttér ilyen mértékü ürességét akkor is érdemes lenne figyelmeztető jelként tekinteni, ha amúgy a gyakorlati alkalmazásban az előrejelző képesség erős lenne. Nem minden pszichológiai terület ennyire gyökértelen. Jól ismert például, hogy a behaviorizmus az angol empirikus filozófiában, illetve a 20. század eleji kontinentális logikai empirizmusban gyökerezik. ${ }^{8}$ A behaviorizmus eredeti álláspontja szerint önmagát természettudományként határozta meg, alapja az empirikus kísérlet, a mérés, anélkül, hogy az ezt előidéző belső állapotokról különböző teóriákat fogalmazna meg. Az empirikus filozófia súlyos elméleti korlátai természetesen jól ismertek, annak David Hume-tól eredő, csaknem önfelszámoló indukcióproblémájától kezdve, ${ }^{9}$ a logikai pozitivista Bécsi Kör szigorú, atomisztikus - és továbbra is indukción nyugvó - ismeretelméleti felfogásán keresztül, ${ }^{10}$ a sokasodó problémák megoldását kereső Karl Popper, Carl Gustav Hempel és egyéb posztpozitivista megoldásokig. A behaviorizmust is komoly és megalapozott kritikával lehet és talán érdemes is illetni, mindazonáltal, tudományfilozófiai szempontból pontosan ez a lényeg. Amennyiben létezik kidolgozott elméleti háttér, akkor az arról meginduló tudományos vita eredményeképpen ez az elméleti háttér letisztul, fejlődik, szélsőséges esetben esetleg felszámolódik, de mindenképpen releváns tudományos vitának ad teret. Ahol elméleti háttér nem igazán létezik, ott a hitbéli meggyőződések, a marketing és üzleti szempontok fognak dominálni, és a tudományosság kritériuma háttérbe szorul.

Az elméleti háttér hiánya magától értetődően nem keverendő össze a hagyomány hiányával. A személyiségvonásokra épülő pszichológia természetesen igen jelentős hagyománnyal rendelkezik. A sokezer éves különböző asztrológiai rendszerektől kezdve a görög származású római Galénosznak a 2. századból származó, testnedveken alapuló tipológiarendszerén ${ }^{11}$ keresztül a 19. század eleji frenológiának a pszichológiai alvilággal határos elméletéig rengeteg kísérlet történt az emberi természet kategorizálására. Ezek az elméletek azonban nem állták ki a tudományosság elemi próbáit sem, és mára elfoglalták helyüket a tudománytörténet megfelelő fejezetében, és Paul Feyerabenden, a zseniális osztrák

Ronald F. Ettinger - C. Eugene Walker: Behaviorism and Existentialism: Views of Skinner and Tillich. Journal of Religion and Health, 5. (1966), 2. 151-157.; Robert C. Olby: Review: The Convergence of Behaviourism and Logical Positivism. History and Philosophy of the Life Sciences, 12. (1990), 1. 117-122.

Charlie Dunbar Broad idézet. Hugh G. Gauch: Scientific Method in Practice. Cambridge University Press, 2002.

Vienna Circle. Stanford Encyclopedia of Philosophy.

Fodor László: Nevezetes személyiségtipológiák. Magiszter, 3. (2005), 4. 3-9. 
filozófuson, a „tudomány legrosszabb ellenségén” kívül komolyan vehető tudósnak nem jutna eszébe, hogy - akárcsak heccből ${ }^{12}$ - érvelni kezdjen mondjuk az asztrológia mint modern értelemben vett tudomány mellett. Ez természetesen a legkevésbé sem akadálya annak, hogy az asztrológia a mai napig is töretlen népszerűséget élvezzen, csakúgy, mint a különböző személyiségtesztek.

\section{EGYMÁSSAL ELLENTÉTES ÁLLÁSPONTOK A SZEMÉLYISÉG TEÓRIÁIBAN}

Filozófiai szempontból figyelemre méltó, hogy a különböző elméletek egymással fedésben nem lévő, illetve - egyes esetekben - össze nem egyeztethető álláspontokat vallanak a személyiségvonásokról, sőt, magáról a személyiségről is.

Allport nyomán a személyiség általánosan elfogadott definíció szerint: „A személyiség azon pszichofizikai rendszerek dinamikus szerveződése az egyénen belül, amelyek meghatározzák jellemző viselkedését és gondolkodását." ${ }^{13} \mathrm{Ez}$ a meghatározás pontosan azért lehet ilyen széles körben elfogadott, mert igen általánosan határozza meg a fogalmat. Nem tudjuk meg például, hogy a személyiséget alapvetően külső környezeti vagy belső tulajdonságok, vagy ezek közösen határozzák meg.

Nincs egyetértés abban sem, hogy a személyiség állandó-e, vagy változik az ember életszakaszainak mentén. Carl Gustav Jung szerint a személyiségtípus az élet során változik, ${ }^{14}$ míg Isabel Myers szerint - aki típuselméletét Jung munkássága alapján építette fel - a személyiség velünk születik és változatlan. A kettejük közti megközelítésbeli különbséget jól mutatja, hogy míg Jung szerint a személyiségtípus meghatározása sokszor igen nagy nehézségekbe ütközik, ${ }^{15}$ addig Myers szerint a személyiség evidensen megmutatkozik néhány alapvető mentális funkció megfigyelése nyomán. ${ }^{16}$ A személyiségvonásoknak az ember életén keresztül megfigyelt állandósága, illetve változékonysága egyébként továbbra is vitatott kérdés, a modern kutatás nem tudta még kimondani a döntő szót. ${ }^{17}$

Az objektív tesztek hívei gyakran éles kritikával illetik a projektív tesztek gyakorlatilag összes pszichometriai jellemzőjét. Alacsony érvényesség és megbízhatóság, valamint túl sok mért változó, ezeket a kritikákat már az 1950-es évek végén Hans Eysenck is megfogalmazta a projektív tesztekkel kapcsolatban. Az objektív teszteknél viszont az a kérdés merül fel, hogy akkor voltaképpen hány személyiségvonásra is lenne szükség? Az MMPI az 1940-es években 15 személyiségvonást mért. Jung 3 ellentétpárral dolgozott, amihez

\footnotetext{
Paul Feyerabend: Három dialógus a tudásról. Budapest, Osiris-Gond, 1999.

Gordon W. Allport: A személyiség alakulása. Budapest, Gondolat, 1980. 39.

Carl Gustav Jung: "Well, you see, the type is nothing static. It changes in the course of life..." BBC interjú, 1959.

Carl Gustav Jung: The First Complete English Edition of the Works of C. G. Jung. Routledge, 1976.

Isabel Briggs Myers - Peter Myers: Gifts Differing: Understanding Personality Type. 2nd edition. CPP, 1995. 1.

Sarah E. Hampson - Lewis R. Goldberg: A First Large-Cohort Study of Personality-Trait Stability Over the 40 Years Between Elementary School and Midlife. Journal of Personality and Social Psychology, 91. (2006), 4. 763-779.
} 
Myers hozzáadott még egyet, így lett a vizsgált személyiségvonások száma immár 4 (MBTI). Raymond Cattell a nyelvből indult ki, Gordon Allport 4504 szavas szótárából, amely tartalmazta az összes személyiségre vonatkozó angol szót, faktoranalízis segítségével végül 16 személyiségvonást különített el (16PF), ez egyébként önmagában is problémás, vitatott alap. Cattell 16 vonását további faktoranalízisnek kitéve jött létre a 3 vonást megkülönböztető NEO, majd ehhez ismét további két személyiségvonást hozzáadva jött létre 1978-ban a NEO PI-R (Revised NEO Personality Inventory), amellyel elérkeztünk a „Big 5” modellig. Legújabban kísérlet történt a Big 5 kiegészítésével egy 6 dimenziós modell megalkotására is „HEXACO” néven. ${ }^{18}$

Önmagában ez a változatosság a vizsgált személyiségvonások számát illetően nem lenne probléma, ha az egy szerves fejlődés lépcsőfokait testesítené meg. A Big 5 rendszerrel kapcsolatban azonban továbbra is megfogalmazódnak nagyjából ugyanazok a gondok, amelyek mindig is együtt jártak a személyiségtesztekkel. Továbbra sincs megalapozott teoretikus háttér, gyenge a predikciós erő, és a személyiségvonások alig több mint felét méri a rendszer. ${ }^{19}$

Ezek nyomán mindenképpen felmerül a kérdés, hogy a személyiségvonások kutatási programja egyáltalán fejlődő program-e, vagy csak - nem egy esetben piaci és marketingszempontok figyelembevételével - egyre újabb formában jelennek meg ugyanazok a tudományosan gyengén alátámasztott módszerek.

\section{ESSZENCIALISTA MEGKÖZELÍTÉS}

$\mathrm{Az}$ ismeretelmélet területén az esszencializmus nézetrendszere szerint minden kutatás végső célja a kutatott jelenség legmélyebb lényegének, „esszenciájának” (etim: latin, „létezés”) feltárása, majd kategorikus definíciókkal történő ellátása. Ebben az értelemben az esszencializmus feltételezi a vizsgált jelenség ilyen értelmű esszenciájának létezését, bizonyos állandóságát és megismerhetőségét.

Az esszencialista megközelítés a múlt század közepére eredeti formájában gyakorlatilag tarthatatlanná vált, Werner Heisenberg határozatlansági elmélete világossá tette, hogy egy ponton túl nincs mód mélyebbre hatolni a fizikai megismerésben, míg filozófiai szempontból Richard Rorty és mások mutatták meg véges lehetőségeit. A tudomány feladata ennek megfelelően immár nem kizárólag, sőt vélhetően nem is elsősorban a jelenségek lényegének esszencialista feltárása, hanem a jelenségek és azok változásainak megbízható előrejelzése. Ebben pedig a modern tudomány szédítő eredményeket ér el.

18 Kibeom Lee - Michael Craig Ashton: The H Factor of Personality: Why Some People are Manipulative, SelfEntitled, Materialistic, and Exploitive - And Why It Matters for Everyone. Wilfrid Laurier University Press, 2012.

19 Gregory J. Boyle - Lazar Stankov - Raymond B. Cattell: Measurement and Statistical Models in the Study of Personality and Intelligence. In Dondald H. Saklofske - Moshe Zeidner (eds.): International Handbook of Personality and Intelligence. 1995. 417-446. 
Lehet, hogy nincs végleges tudásunk az anyag legmélyebb valóságáról, de kiváló és megbízható előrejelzéseket tudunk tenni, és igen komplex technológiákat vagyunk képesek ezen előrejelzések alapján felépíteni és működtetni. Tudományos programjaink egyértelmű elörehaladást mutatnak, még abban az esetben is, amikor az esszencialista megismerési szempontot másodlagosként kezeljük.

A kiválasztási folyamatban használt pszichológiai személyiségtesztek bizonyos értelemben esszencialista megközelítést tükröznek. A vizsgált alany személyiségére, mély önazonosságára vagyunk kíváncsiak, azt próbáljuk megragadni és előre meghatározott kategóriák szerint osztályozni, az eddigi tapasztalatok szerint igen szerény eredménynyel. A kiválasztási folyamatban használt képességtesztek ilyen értelemben messze hasznosabbnak tűnnek. A munkahelyi megfelelés szempontjából nem az a lényeg, hogy „ki” az alany, hanem az, hogy „mit tud”. Nem azt elemezzük, amit magáról állít egy önbevalláson alapuló tesztben, hanem azt mérjük egzakt módon, hogy mire képes. Lehet, hogy például az intelligencia konstruktumával kapcsolatban vannak még nyitott kérdések, de ez nem akadályoz meg minket abban, hogy igen megbízhatóan mérjük az intelligencia mértékét, és megbízható elörejelzéseket tudjunk tenni ennek mentén a teszt alanyának várható teljesítményével kapcsolatban.

Végezetül fontos látni azt is, hogy bármilyen fejlett statisztikai apparátust eresztünk rá egy kérdéses megbízhatóságú, mondjuk önbevalláson alapuló adathalmazra, az elemzés végeredménye ettől nem lesz jobb. Legfeljebb szofisztikált öltözetben lesz megbízhatatlan. Másfelől, feltételezhetően a legtöbb szakembert igen nehezen lehetne meggyőzni arról, hogy mondjuk, az intelligenciahányadost ezen túl érdemesebb lenne képességteszt helyett önbevallás útján meghatározni. Ennek legfeljebb abban az esetben lenne értelme, ha mondjuk a valódi értékkel összehasonlítva a saját magunkról bennünk kialakult, a valóságnál kedvezőbb képben megragadható kognitív torzítást vizsgálnánk.

\section{A KONSTRUKTUMOK PROBLEMATIKÁJA}

A személyiségvonások közvetlenül nem megfigyelhetők, így azok elméleti konstruktumoknak tekinthetők. A személyiségvonásoknak elméleti szempontból két lehetséges értelmezése van. Az egyik - mondjuk kauzális esszencialista - megközelítés szerint a személyiségvonások olyan belső hajtóerők, amelyek konzekvensen bizonyos típusú cselekvésekben manifesztálódnak. A másik - nominalista deskriptív - megközelítés szerint ezek a személyiségvonások egyszerüen bizonyos típusú cselekedeteink leíró megnevezése, anélkül, hogy bármilyen belső állapottal vagy diszpozícióval való ok-okozati összefüggést feltételezne. ${ }^{20}$

A kauzális elmélet esetében érdekes problémába botlunk. A példa kedvéért vizsgáljuk meg az „idegesség” konstruktumát. Ezt a konstruktumot abból nyerjük, hogy megfigyeljük egyes

20 Steve Abel: What Is a Trait: Two Basic Formulations. 2015. 
tesztalanyoknak az „ideges” viselkedését és abból egy elvont „idegesség”-konstruktumot alkotunk. Ezek után, ha további tesztalanyokat figyelünk meg, akkor honnan tudjuk, hogy valaki ideges? Onnan, hogy idegességet mutatóan viselkedik. Azért viselkedik idegességet mutatóan, mert ideges. Ez így viszont egy körkörös érvelés, amely csak olyan módon lenne felbontható, ha az „idegesség” személyiségvonása és az „ideges” viselkedés egymástól függetlenül azonosítható lenne. Csakhogy a személyiségvonást éppen a viselkedés megfigyeléséből alkottuk meg, mint konstruktumot.

A deskriptív elmélet esetében ez a probléma nem jelenik meg, fellép viszont egy más típusú nehézség. A kauzális elmélet esetében világos volt, hogy cselekvéseink belső diszpozícióink, személyiségvonásaink által meghatározottak. A deskriptív elmélet azonban nem tesz feltételezést a viselkedés kiváltó okával kapcsolatban, így erőteljesen megjelenhetnek például környezeti hatások is. Nézzük példaként a „féltékenység” fogalmát. Valakiről azt állítjuk, hogy féltékenységet mutató módon viselkedik, mert kisajátítja partnerét, ellenőrzi, ragaszkodik ahhoz, hogy folyamatosan viselje a tőle kapott gyürüt, de megrója azért, ha mindig kisminkeli magát, stb. Ezekben a viselkedési formákban tetten érhető a féltékenység személyiségvonása, ám ennek okairól nem történik említés. Így megtörténhet természetesen, hogy ez a személyiségvonás az illető mély belső diszpozíciója (például mély önbizalomhiány okozza), de létrejöhet döntően szituációs hatás következtében is, például, ha az illető azt tapasztalja, hogy más férfiak nagy erőkkel ostromolják a feleségét. ${ }^{21}$

Gyakorlatibb irányba elmozdulva számos kritika fogalmazódik meg azzal kapcsolatban, ahogy a különböző konstruktumokra a tesztek kontextus nélkül rákérdeznek, például „[ö]nmagát inkább »megbocsátónak« vagy »igazságosnak« jellemezné?”. Vagy amikor például arról kell nyilatkozni, hogy emberek egy meghatározatlan csoportja miképpen vélekedik, például „[n]émelyek azt gondolják rólam, hogy hideg és számító vagyok” (NEO PI-R). Ezekre a levegőben lógó kérdésekre nem lehet egy ötfokú skálán komolyan vehető választ adni. ${ }^{22}$

\section{KONKLÚZIÓ}

A tudomány jelenlegi állása szerint a személyiségtesztek - miközben klinikai környezetben hasznos és bevált eszközöknek bizonyulnak - a kiválasztási folyamatban nem képesek azt a szerepet betölteni, amit nekik tulajdonítanak. A személyiségtesztek pszichometriai jellemzői nem meggyőzők, elméleti hátterük gyenge, gyakorlati hasznuk megkérdőjelezhető.

A személyiségteszteknek e tényeket meghazudtoló népszerűségükben vélhetően lényeges szerepet játszik a Barnum-hatás, ${ }^{23}$ a személyes megerősítés téveszméje, amikor egy egyén nagy valószínűséggel bármely felületes, közhelyes, a részletekbe nem bocsátkozó személyiségjellemzést

\footnotetext{
Abel (2015) i. m.

22 Anne Murphy Paul: The Cult of Personality Testing: How Personality Tests Are Leading Us to Miseducate Our Children, Mismanage Our Companies, and Misunderstand Ourselves. New York, Free Press, 2005.

Grant (2013) i. m.
} 
találónak és magára illőnek fog találni, ha azt a meggyőződést keltik benne, hogy az kifejezetten az ő számára készült. Egyes tesztek, leginkább az MBTI, kifejezetten pozitív fogalomhasználattal értékelnek, ami igen kedvező benyomást tesz a tesztalanyokra, erősítve az „Aha, ez tényleg én vagyok!" érzést.

A munkaerő-kiválasztási folyamatban kétségtelenül igen hosszú hagyománya van a személyiségtesztek használatának. Ugyanilyen kétségtelen az is, hogy ez alatt a hosszú idő alatt tudományos kutatások százai figyelmeztettek a személyiségtesztek elméleti és pszichometriai gyengeségére. A fizetőképes kereslet azonban természetesen megteremti a kínálatot, így újabb és újabb elnevezéssel jelennek meg újabb és újabb tesztek, amelyek sokat ígérnek, de egyelőre mérsékelt sikerrel teljesítenek.

Lényeges, hogy e teszteknek létezik reális alternatívája. Egyfelől a kiválasztásnál érdemes elmozdulni a képességtesztek használatának nagyobb aránya felé. Ilyen új típusú képességteszt racionális gondolkodás mérésére szolgáló képességteszt, ${ }^{24}$ amely egészen új lehetőségeket kínál a kiválasztásban és a munkaerőképzésekben. ${ }^{25}$ A személyiségről mélyebb és megbízhatóbb képet lehet kapni strukturált kvalitatív interjúval vagy az egyén megfigyelésével különböző tervezett szituációkban. Ezek természetesen jóval idő- és ráfordításigényesebb módszerek, de tudományos szempontból jóval megbízhatóbbak.

${ }^{24}$ Keith E. Stanovich - Richard F. West - Maggie E. Toplak: The Rationality Quotient. Toward a Test of Rational Thinking. The MIT Press, 2015.

25 Makay Mátyás: A racionális gondolkodás képességének kvantitatív mérése. Katonai Nemzetbiztonsági Szolgálat Szakmai Szemle, 15. (2017), 3. 


\section{FELHASZNÁLT IRODALOM}

1. Abel, Steve: What Is a Trait: Two Basic Formulations. 2015. Elérhetö: www.doctorabel.us/ personality-psychology/what-is-a-trait-two-basic-formulations.html (A letöltés dátuma: 2020. 09. 14.)

2. Allport, Gordon W: A személyiség alakulása. Budapest, Gondolat, 1980.

3. Boyle, Gregory J. - Stankov, Lazar - Cattell, Raymond B.: Measurement and Statistical Models in the Study of Personality and Intelligence. In Saklofske, Donald H. - Zeidner, Moshe (szerk.): International Handbook of Personality and Intelligence. 1995. 417-446. DOI: 10.1007/978-1-4757-5571-8_20

4. Driver, Russel W. - Bruckley, M. Donald - Frink, Dwight D.: Should We Write Off Graphology? International Journal of Selection and Assessment, 4. (1996), 2. 78-86. DOI: $10.1111 /$ j.1468-2389.1996.tb00062.x

5. Emotional Breakdown. The Economist, 2013. Elérhető: www.economist.com/news/ business/21575817-can-leaders-be-identified-psychometrics-emotional-breakdown (A letöltés dátuma: 2020. 09. 14.)

6. Ettinger, Ronald F. - Walker, C. Eugene: Behaviorism and Existentialism: Views of Skinner and Tillich. Journal of Religion and Health, 5. (1966), 2. 151-157. DOI: 10.1007/ bf01532643

7. Feyerabend, Paul: Három dialógus a tudásról. Budapest, Osiris-Gond, 1999.

8. Fodor László: Nevezetes személyiségtipológiák. Magiszter, 3. (2005), 4. 3-9. Elérhető: http://rmpsz.ro/uploaded/tiny/files/magiszter/2005/tel/1.pdf (A letöltés dátuma: 2020. 09. 14.)

9. Gardner, William L. - Martinko, Mark J.: Using the Myers-Briggs Type Indicator to Study Managers: A Literature Review and Research Agenda. Journal of Management, 22. (1996), 1. 45-83. DOI: 10.1177/014920639602200103

10. Gauch, Hugh G.: Scientific Method in Practice. Cambridge University Press, 2002. DOI: $10.1017 / \mathrm{CBO} 9780511815034$

11. Grant, Adam: Goodbye to MBTI, the Fad That Won't Die. Psychology Today, 2013. Elérhető: www.psychologytoday.com/blog/give-and-take/201309/goodbye-mbti-the-fadwon-t-die (A letöltés dátuma: 2020. 09. 14.)

12. Hampson, Sarah E. - Goldberg, Lewis R.: A First Large-Cohort Study of PersonalityTrait Stability Over the 40 Years Between Elementary School and Midlife. Journal of Personality and Social Psychology, 91. (2006), 4. 763-779. DOI: 10.1037/00223514.91.4.763

13. Jung, Carl Gustav: The First Complete English Edition of the Works of C. G. Jung. Routledge, 1976.

14. Jung, Carl Gustav: "Well, you see, the type is nothing static. It changes in the course of life...” BBC interjú, 1959.

15. Lee, Kibeom - Ashton, Michael Craig: The H Factor of Personality: Why Some People are Manipulative, Self-Entitled, Materialistic, and Exploitive - And Why It Matters for Everyone. Wilfrid Laurier University Press, 2012. 
16. Lilienfeld, Scott O. - Wood, James M. - Garb, Howard N.: The Scientific Status of Projective Techniques. Psychological Science in the Public Interest, 1. (2000), 2. 27-66. DOI: 10.1111/1529-1006.002

17. Makay Mátyás: A racionális gondolkodás képességének kvantitatív mérése. Katonai Nemzetbiztonsági Szolgálat Szakmai Szemle, 15. (2017), 3. 155-174. Elérhető: www. knbsz.gov.hu/hu/letoltes/szsz/2017_3_szam.pdf (A letöltés dátuma: 2020. 09. 14.)

18. Morgeson, Frederick P. - Campion, Michael A. - Dipboye, Robert L. - Hollenbeck, John R. - Murphy, Kevin - Schmitt, Neal: Are We Getting Fooled Again? Coming to Terms with Limitations in the Use of Personality Tests for Personnel Selection. Personnel Psychology, 60. (2007), 4. 1029-1049. DOI: 10.1111/j.1744-6570.2007.00100.x

19. Myers, Isabel Briggs - Myers, Peter: Gifts Differing: Understanding Personality Type. $2^{\text {nd }}$ edition. CPP, 1995.

20. Olby, Robert C.: Review: The Convergence of Behaviourism and Logical Positivism. History and Philosophy of the Life Sciences, 12. (1990), 1. 117-122.

21. Paul, Anne Murphy: The Cult of Personality Testing: How Personality Tests Are Leading Us to Miseducate Our Children, Mismanage Our Companies, and Misunderstand Ourselves. New York, Free Press, 2005.

22. Stanovich, Keith E. - West, Richard F. - Toplak, Maggie E.: The Rationality Quotient. Toward a Test of Rational Thinking. The MIT Press, 2015. DOI: 10.7551/mitpress/ 9780262034845.001.0001

23. Vienna Circle. Stanford Encyclopedia of Philosophy. Elérhető: https://plato.stanford. edu/entries/vienna-circle/ (A letöltés dátuma: 2020. 09. 14.) 
Makay Mátyás az ELTE Pszichológia Doktori Iskola doktorjelöltje, kutatási területe a kognitív torzítások kvantitatív mérése és a kognitív torzítások csökkentésére használt eszközök. Makay Mátyás közgazdász, majd filozófus és tanár MA képzettséget szerzett, a filozófia területén elsősorban ismeretelmélettel és tudományfilozófiával foglalkozott, illetve tanított különböző egyetemeken. 